\title{
Is Escherichia coli growing in glucose-limited chemostat culture able to utilize other sugars without lag?
}

\author{
Urs Lendenmann $\nmid$ and Thomas Egli
}

Author for correspondence: Thomas Egli. Tel: +41 182351 58. Fax: +4118235547.

Swiss Federal Institute for Environmental Sciences and Technology (EAWAG), Swiss Federal Institute of Technology (ETH), Überlandstrasse 133 CH-8600 Dübendorf,

Switzerland

\begin{abstract}
It was investigated whether Escherichia coli cultured in a glucose-limited chemostat is able to grow with a series of sugars whose utilization is normally repressed during batch growth with glucose. Cells growing at dilution rates of $0.2,0.3$ and $0.6 \mathrm{~h}^{-1}$ were able to immediately utilize and grow with fructose, mannose, maltose and ribose. Galactose was transported instantaneously but growth started only after a considerable lag. Arabinose was the only sugar tested which was neither transported nor utilized immediately. The results give experimental evidence that in vivo catabolite repression by glucose is absent at the very low glucose concentrations present in chemostat culture. Additionally, the results demonstrate that chemostat-grown cells of $E$. coli are able to substitute glucose as a carbon and energy source by several other sugars with no lag period.
\end{abstract}

Keywords: Escherichia coli, sugar transport, continuous culture

\section{INTRODUCTION}

Escherichia coli usually exhibits diauxic growth when presented with mixtures of carbon substrates in batch culture (Monod, 1942). Catabolite repression (Postma \& Lengeler, 1993) and inducer exclusion (Kornberg et al., 1980) were identified as the main mechanisms inhibiting the utilization of secondary substrates. In contrast, in carbon-limited chemostat cultures E. coli utilizes mixtures of sugars simultaneously (Mateles et al., 1967; Lendenmann, 1994). Therefore, it was assumed that in carbonlimited chemostat culture glucose concentrations are too low to repress utilization of other carbon substrates (Harder \& Dijkhuizen, 1982). It is now well established and has been demonstrated for many micro-organisms that in carbon-limited continuous culture mixtures of carbon sources are utilized simultaneously at low and intermediate dilution rates (Harder \& Dijkhuizen, 1976; Egli et al., 1993). Under such conditions it has been shown that with decreasing dilution rate the synthesis of a wide

†Present address: ALEQC, 139 Barnes Drive, Tyndall AFB, Florida 32403, USA.

Abbreviations: $\mu_{\text {excess }}$ specific growth rate exhibited by chemostat-grown cells when transferred into a medium containing excess of a carbon substrate; $q_{\text {excess }}$ specific substrate uptake rate exhibited by chemostatgrown cells under substrate excess conditions; PTS, phosphotransferase system. range of catabolic enzymes becomes derepressed (Matin, 1979). This implies that E. coli should be able to immediately utilize other sugars on condition that the enzymes required for their transport and utilization are expressed in the absence of the specific inducer. Therefore, it may be possible that $E$. coli growing in glucose-limited chemostat culture is able to immediately utilize a range of sugars, whereas the utilization of some other sugars will start only after a lag required for induction and expression of the specific enzymes.

In order to test which sugars are immediately transported and are able to support growth, E. coli was cultivated in glucose-limited chemostat culture at three different dilution rates. Cells removed from the bioreactor were exposed to excess concentrations $\left(5 \mathrm{mg} \mathrm{l}^{-1}\right)$ of either glucose, fructose, mannose, galactose, maltose, ribose or arabinose and the rate of sugar consumption was measured. Additionally, chemostat-grown cells were inoculated into batch cultures containing these sugars as the sole source of carbon and energy, and growth was determined.

\section{Transport of the sugars used in this study}

Three mechanisms are involved in the transport of the sugars used in this study with E. coli: group translocation catalysed by the phosphoenolpyruvate-dependent phosphotransferase systems (PTS) (Meadow et al., 1990; 
Postma \& Lengeler, 1985), binding-protein-dependent transport (Furlong, 1987), and chemiosmotic-driven transport (Henderson, 1990). Glucose is transported mainly via PTS ${ }^{\mathrm{Glc}}$. Alternatively, the PTSs of mannose (PTS $^{\text {Man }}$ ) (Postma \& Lengeler, 1993), fructose (PTS ${ }^{\text {Fru }}$ ) and sucrose (PTS ${ }^{\text {Scr }}$ ) (Postma \& Lengeler, 1985), as well as the proton symport (GalP) and the binding-proteindependent transport $(\mathrm{Mgl})$ systems of galactose allow uptake of glucose (Henderson et al., 1977). PTS ${ }^{\text {Fru }}$ transports fructose into the cell resulting in intracellular fructose 1-phosphate. Alternatively, the PTS for glucitol (PTS $^{\text {Gut }}$ ) and PTS ${ }^{\text {Man }}$ transport fructose with lower affinity (Postma \& Lengeler, 1985). Mannose is mainly transported by PTS ${ }^{\text {Man }}$ (Postma \& Lengeler, 1985). Other systems transporting mannose with lower affinity are PTS $^{\text {Gle }}$, PTS ${ }^{\text {fru }}$ (Postma \& Lengeler, 1993) and the proton symporters of rhamnose and galactose (Henderson, 1990). A binding-protein system catalyses maltose uptake and to date no other transport system for maltose is known in E. coli. Ribose is mainly transported by its binding-protein system (Rbs) (Lopilato et al., 1984). At least six different systems are presently known to transport galactose in E. coli (Furlong, 1987). Two of them are specific for galactose: the binding-protein system (Mgl) (Furlong, 1987) and the proton-driven galactose permease (GalP) (Henderson, 1990). Other systems accepting galactose as a substrate are the lactose permease (LacY), the melibiose transport system (MelB) and the two transport systems for arabinose (Furlong, 1987). Three transport systems have been described mediating arabinose uptake: the low-affinity proton-linked system (AraE), the high-affinity binding-protein system (AraFGH) and to a lesser extent also the binding-protein system of galactose (Mgl) (Furlong, 1987).

\section{Catabolite repression}

The phenomenon of several genes encoding transport and metabolism of a series of carbohydrates not being expressed in the presence of glucose or other PTS carbohydrates is called catabolite repression. Expression of these genes requires cyclic AMP (cAMP) (Ullmann \& Danchin, 1983). In the presence of PTS carbohydrates adenylate cyclase is almost inactive (Peterkofsky \& Gazdar, 1974) and consequently the intracellular level of cAMP is very low (Makman \& Sutherland, 1965). This results in a low transcription rate of cAMP-dependent regulons (Magasanik \& Neidhardt, 1987). Several mechanisms which have been proposed to account for this effect are presently under investigation (Saier, 1991). On the basis of genetic studies regulation of the activity of adenylate cyclase seems to involve IIA ${ }^{\text {Gle }}$. However, to date there is no biochemical proof that IIA ${ }^{\text {Gle }}$ interacts directly with adenylate cyclase (Postma \& Lengeler, 1993).

Inducer exclusion is irrelevant under the conditions used in this study because in glucose-limited chemostat culture of $E$. coli the steady-state substrate concentrations are very low, i.e. 140,40 and $16 \mu \mathrm{g} \mathrm{l}^{-1}$ for the tested dilution rates of $0 \cdot 6,0.3$ and $0.2 \mathrm{~h}^{-1}$, respectively (Senn et al., 1994).
Consequently, all residual glucose was exhausted prior to the uptake and batch experiments.

\section{METHODS}

Organism. Escherichia coli ML30 (DSM 1329) was used in all experiments.

Medium. The mineral medium contained, per litre: $2 \cdot 72 \mathrm{~g}$ $\mathrm{KH}_{2} \mathrm{PO}_{4}, 0.763 \mathrm{~g} \mathrm{NH}_{4} \mathrm{Cl}, 82 \mathrm{mg}$ EDTA. $\mathrm{Na}_{2} .2 \mathrm{H}_{2} \mathrm{O}, 59 \mathrm{mg}$ $\mathrm{MgSO}_{4} \cdot 7 \mathrm{H}_{2} \mathrm{O}, 2.6 \mathrm{mg} \quad \mathrm{Na}_{2} \mathrm{MoO}_{4} \cdot 2 \mathrm{H}_{2} \mathrm{O}, 10 \mathrm{mg} \mathrm{CaCO}_{3}$, $2.03 \mathrm{mg} \mathrm{FeCl}{ }_{3} .6 \mathrm{H}_{2} \mathrm{O}, 4.95 \mathrm{mg} \mathrm{MnCl}_{2} .4 \mathrm{H}_{2} \mathrm{O}, 1.02 \mathrm{mg} \mathrm{ZnO}$, $0.85 \mathrm{mg} \mathrm{CuCl}{ }_{2} .2 \mathrm{H}_{2} \mathrm{O}, 1.20 \mathrm{mg} \mathrm{CoCl}_{2} .6 \mathrm{H}_{2} \mathrm{O}$ and $0.31 \mathrm{mg}$ $\mathrm{H}_{3} \mathrm{BO}_{3}$. Chemicals were purchased either from Fluka or Merck. Prior to heat sterilization $\mathrm{pH}$ was adjusted to approximately 3 with conc. $\mathrm{H}_{2} \mathrm{SO}_{4}$. D-Glucose at a concentration of $100 \mathrm{mg} \mathrm{l}^{-1}$ served as growth-limiting source of carbon and energy. Glucose was dissolved in approximately $200 \mathrm{ml}$ water adjusted to $\mathrm{pH} 3$ with $\mathrm{HCl}$ and sterilized separately to prevent formation of derivatives. Only sugars of the highest purity commercially available were used. Purity of glucose was higher than $99 \cdot 5 \%$. Our own tests indicated that after sterilization of the glucose solution only about $15 \mu \mathrm{g}$ fructose $\mathrm{l}^{-1}$ was present in a growth medium consisting of $100 \mathrm{mg}$ glucose $\mathrm{l}^{-1}$, whereas concentrations of the other sugars used in this study were below the detection limit $\left(<5 \mu \mathrm{g} \mathrm{l}^{-1}\right)$.

Cultivation. Chemostat culture was performed in a $2.51 \mathrm{mini}$ reactor (MBR, Wetzikon, Switzerland) with a working volume of 1.61 . An aeration rate of 1 v.v.m. (vol. vol. $\mathrm{min}^{-1}$ ) and a stirrer speed of 1000 r.p.m. ensured a partial pressure of oxygen above $80 \%$ of saturation. The temperature was $37 \pm 0.1{ }^{\circ} \mathrm{C}$ and $\mathrm{pH}$ was controlled at $7 \cdot 0 \pm 0.05$ by automatic addition of $\mathrm{NaOH} / \mathrm{KOH}, 1 \mathrm{M}$ each, or $\mathrm{H}_{3} \mathrm{PO}_{4}(10 \%, \mathrm{v} / \mathrm{v})$. Biomass concentration was followed by measuring $\mathrm{OD}_{546}$ using a cuvette with a light path of $5 \mathrm{~cm}$.

Uptake rates. The ability of chemostat-grown E. coli cells to transport different sugars was tested in uptake experiments. Culture liquid $(50 \mathrm{ml})$ was withdrawn from the chemostat and immediately incubated at $37^{\circ} \mathrm{C}$ in a pre-warmed $200 \mathrm{ml}$ Erlenmeyer flask. No pre-treatment was used because washing has been reported to reduce the capacity of bacteria to incorporate glucose (Herbert \& Kornberg, 1976). Aeration was ensured by mixing the culture with a magnetic stirrer at 500 r.p.m. One minute after removal from the chemostat, cells were exposed to D-arabinose, D-fructose, D-galactose, D-glucose, Dmaltose monohydrate, D-mannose or D-ribose, each one at a time, by adding the sugars from a stock solution of $1 \mathrm{~g} \mathrm{l}^{-1}$ to a final concentration in the assay of $5 \mathrm{mg} \mathrm{l}^{-1}$. The rate of sugar uptake was measured by following substrate depletion. The first sample was removed at $t=6 \mathrm{~s}$ and subsequent samples at intervals of $30 \mathrm{~s}$ to $2 \mathrm{~min}$ after addition of the sugars. Filtration of the samples was performed with a sampling manifold (Millipore) using hydrophilic polyvinylidendifluoride filters with a pore size of $0.22 \mu \mathrm{m}$ and a diameter of 25 millimetres (Millipore). Total filtration time was approximately $15 \mathrm{~s}$. Samples were stored on ice for no more than $1.5 \mathrm{~h}$ before preparation for sugar analysis. To examine growth during the assay, optical density of the culture was measured before sugar addition and after removing the last sample. Specific uptake rates [g sugar transported ( $g$ bacterial dry $w t)^{-1} h^{-1}$ ] were derived from the linear part of the substrate depletion curve. Dry weight was estimated from $\mathrm{OD}_{546}$ measured in a cuvette with a light path of $5 \mathrm{~cm}$. The conversion factor was $0.0626 \mathrm{~g}$ dry wt $1^{-1}$ per $O_{546}$ unit. Preliminary control experiments demonstrated that uptake rates were similar for initial sugar concentrations of 2,5 and $10 \mathrm{mg} \mathrm{l}^{-1}$ and the consumption rate 
was not affected significantly if sugars were added 1, 2 or 4 min after removal of the cells from the chemostat.

Sugar analysis. Analysis included desalting of samples by electrodialysis and subsequent sugar determination with HPLC separation, post-column reaction with alkaline copper(II) bisphenanthroline and amperometric detection. The method for sugar analysis has previously been published in detail (Senn et al., 1994; Lendenmann, 1994).

Growth experiments. Batch growth with different sugars was carried out at $37^{\circ} \mathrm{C}$ in pre-warmed $200 \mathrm{ml}$ Erlenmeyer flasks to which had previously been added $5 \mathrm{mg}$ of one of the following sugars: glucose, galactose, maltose, ribose, fructose, arabinose and mannose. These flasks were filled with $50 \mathrm{ml}$ culture solution from the chemostat, resulting in an initial sugar concentration of $100 \mathrm{mg} \mathrm{l}^{-1}$. The time required for transfer $(1 \mathrm{~min})$ ensured that no residual glucose was initially present in the batch culture $\left(<3 \mu \mathrm{g} \mathrm{l}^{-1}\right)$. Growth was followed by measuring $\mathrm{OD}_{546}$ using a $1 \mathrm{~cm}$ cuvette.

At each dilution rate tested, uptake and batch experiments were performed in duplicate. Uptake and growth rates differed usually by no more than $\pm 10 \%$, whereas in the case of galactose and arabinose lag times before growth started exhibited considerable variation $( \pm 50 \%)$.

\section{RESULTS AND DISCUSSION}

\section{Glucose utilization by glucose-grown cells}

As a control, glucose utilization by glucose-grown cells was tested. The specific growth rate $\left(\mu_{\text {excess }}\right)$ that cells exhibited $0.5 \mathrm{~h}$ after transfer from chemostat into batch culture exceeded the dilution rate at which they were grown in the chemostat and, additionally, $\mu_{\text {excess }}$ depended on the dilution rate (Fig. 1). During the batch experiment $\mu_{\text {excess }}$ increased slightly over a period of $2 \mathrm{~h}$

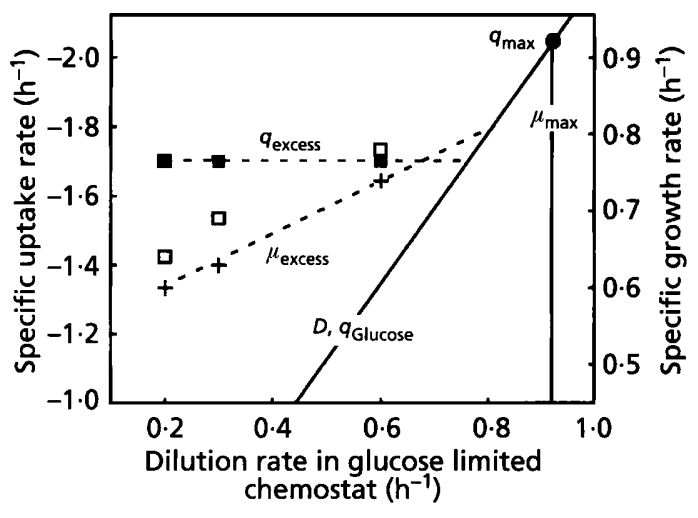

Fig. 1. Specific excess glucose uptake rate and specific growth rate of $E$. coli grown in a glucose-limited chemostat at three different dilution rates when exposed to excess glucose concentrations. $\square$, Specific excess uptake rate $\left(q_{\text {excess }}\right) ;+$, specific excess growth rate $\left(\mu_{\text {excess }}\right)$ attained in batch culture immediately $(0.5 \mathrm{~h})$ after removal from chemostat; $\square$, specific growth rate observed after $1.5 \mathrm{~h}$ of growth in batch culture; - specific glucose consumption rate in the chemostat. The scales are chosen such that the uptake rate multiplied by the growth yield $\left[0.45 \mathrm{~g}\right.$ dry wt (g sugar) $\left.^{-1}\right]$ corresponds to the growth rate. The growth yield was identical for all sugars used.
(Fig. 1). However, $\mu_{\text {excess }}$ always remained considerably lower than the $\mu_{\max }$ of $0.92 \mathrm{~h}^{-1}$ that $E$. coli typically attained in batch culture with glucose (Senn $e t$ al., 1994).

The specific uptake rate for glucose ( $\left.q_{\text {excess }}\right)$ was always approximately $-1.7 \mathrm{~h}^{-1}$ and exhibited no dependence on the dilution rate (Fig. 1). This indicates that PTS ${ }^{\text {Glc }}$ worked at sub-saturated levels during growth at low dilution rates. However, the $q_{\text {excess }}$ of $-1.7 \mathrm{~h}^{-1}$ did not exceed by much the physiological requirements of cells at high growth rates (Fig. 1). It should be pointed out that $q_{\text {excess }}$ multiplied by the growth yield corresponded well to the maximum value of $\mu_{\text {excess }}=0.76 \mathrm{~h}^{-1}$ exhibited by chemostat-grown cells when transferred into batch culture (Fig. 1).

\section{Metabolic capacity of glucose-grown cells}

Measurements of the glucose uptake rate and the growth rates gave information about the maximum metabolic capacity of chemostat-grown cells. The experiment in Fig. 1 illustrated that the cells were able to transport glucose at a constant high rate independent of the dilution rate used. This can be explained by previous findings that in E. coli $\mathrm{B} / \mathrm{r}$ the PTS activity remained more or less constant at different dilution rates (Leegwater, 1983). The batch growth rate achieved was considerably lower than $\mu_{\max }$ and linearly dependent on the pre-growth dilution rate. The results confirm the previously reported inability of $E$. coli to immediately increase the rate of growth when transferred from continuous culture to substrate-excess conditions (Harvey, 1970). This raises the question of the fate of the surplus glucose transported under excess conditions into the cell and that required for growth. Previously reported experiments supply a possible explanation to this question (Neijssel et al., 1977). When excess glucose was added to a glucose-limited chemostat culture, increased oxygen consumption rates were observed as long as the dilution rate was below $0.7 \mathrm{~h}^{-1}$. This indicated that the bacteria still had excess capacity to metabolize glucose at these growth rates. At dilution rates higher than $0 \cdot 7-0 \cdot 8 \mathrm{~h}^{-1}$ no excess capacity was observed. The growth rate of $0.7 \mathrm{~h}^{-1}$, where no excess oxygen consumption capacity remained, corresponded nicely to the rate at which $q_{\text {excess }}$ was equal to $\mu_{\text {excess }}$ in this study (Fig. 1). Furthermore, the pattern of the oxygen consumption rate reported by Neijssel and co-workers corresponded exactly to the $\mu_{\text {excess }}$ measured in this investigation. This indicates that the glucose taken up in excess was most probably accumulated transiently or excreted in the form of metabolites, e.g. acetate (Holms, 1986; El-Mansi \& Holms, 1989), until a new balance between growth and substrate uptake was achieved. The now evident decrease of the excess metabolic capacity at higher dilution rates may also be a consequence of the often observed decreasing level of catabolic enzymes in cells with increasing dilution rate (Egli et al., 1980; Matin, 1979).

It should be pointed out that the $\mu_{\text {excess }}$ of $0.76 \mathrm{~h}^{-1}$ is very close to the $\mu_{\max }$ of $0.80 \mathrm{~h}^{-1}$ obtained when fitting the 


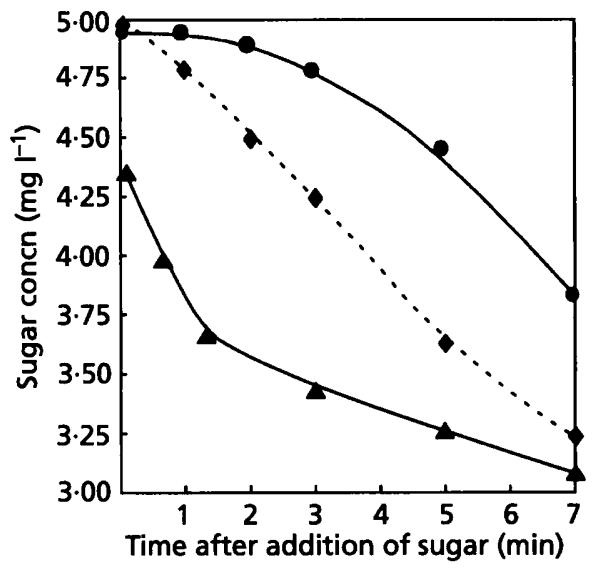

Fig. 2. Uptake patterns observed for galactose ( $\Delta$ ), fructose $(\Theta)$, and ribose $(\bullet)$ by $E$. coli grown in glucose-limited chemostat culture. Cells were grown at a dilution rate of $0.2 \mathrm{~h}^{-1}, 0.3 \mathrm{~h}^{-1}$ and $0.6 \mathrm{~h}^{-1}$ in the case of the galactose, fructose and ribose uptake experiment, respectively. Depletion curves were comparable for all three dilution rates tested. The initial biomass concentration was $45 \mathrm{mg} \mathrm{l}^{-1}$. The plot from the ribose experiment represents a normally observed depletion curve.

Monod model to steady-state glucose concentration data determined in continuous culture (Senn et al., 1994). In contrast, the $\mu_{\max }$ of $0.92 \mathrm{~h}^{-1} E$. coli exhibited when 'trained' to batch culture is considerably higher. This provides further evidence that bacteria adapted to chemostat growth do not grow at the maximum possible rate and that not only the 'apparent' $K_{\mathrm{s}}$ (Senn et al., 1994) but also the 'apparent' $\mu_{\max }$ is subjected to change.

\section{Transport of and growth with other sugars}

When cells of E. coli grown in glucose-limited chemostat culture were exposed to excess concentrations of sugars other than glucose they were able to transport and grow on mannose, maltose and ribose without any detectable lag. For fructose the initial uptake rates were low but after a lag of approximately $3 \mathrm{~min} q_{\mathrm{Fru}}$ increased to a specific rate between 0.3 and $0.5 \mathrm{~h}^{-1}$, as can be derived from the time course of the sugar concentration (Fig. 2). Galactose was immediately transported but growth started only after a lag of $10-50 \mathrm{~min}$. During the first minute galactose was removed quickly but then the rate decreased to approximately one-fifth of the initial value. This resulted in characteristic depletion curves for fructose and galactose during the uptake assay (Fig. 2). A considerable lag for both transport and metabolism was observed only for arabinose. When the cells were grown at $D=0.2 \mathrm{~h}^{-1}$, arabinose uptake started after $6 \min \left(q_{\text {Ara }} \approx 0 \cdot 02-0 \cdot 1 \mathrm{~h}^{-1}\right)$ and the lag until growth started was about $20 \mathrm{~min}$. However, at higher dilution rates no transport was observed within $10 \mathrm{~min}$ and growth began only after a lag of more than $30 \mathrm{~min}$.

For a particular sugar the qualitative uptake patterns were similar for all dilution rates tested but a distinct dependence of the initial specific uptake rate on the dilution

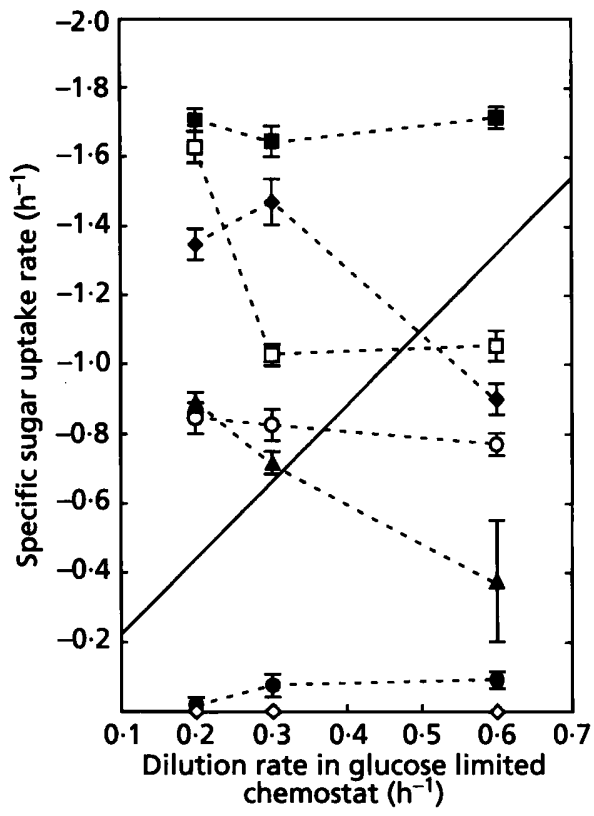

Fig. 3. Specific uptake rates for various sugars [glucose (a), fructose (O), mannose $(O)$, maltose $(\square)$, ribose $(\diamond)$, galactose $(\Delta)$ and arabinose $(\diamond)$ ] exhibited by $E$. coli grown in glucoselimited chemostat culture at three different dilution rates. Specific glucose consumption rate in the chemostat.

rate was found. Specific uptake rates for maltose, galactose and ribose decreased with increasing dilution rate, those for glucose and mannose remained approximately constant, whereas the specific uptake rate for fructose increased, slightly but significantly, with increasing dilution rate (Fig. 3).

\section{Regulation of sugar utilization in the absence of the inducer}

The specific growth rates that cells exhibited in batch culture $2 \mathrm{~h}$ after removal from the chemostat were, as a rule, higher than the dilution rate at which they were cultivated. Cells grown at $D=0 \cdot 2 \mathrm{~h}^{-1}$ exhibited specific growth rates between $0.45 \mathrm{~h}^{-1}$ (with mannose) and $0.58 \mathrm{~h}^{-1}$ (with fructose). Cultivated at $D=0.3 \mathrm{~h}^{-1}$ the rates were between $0.48 \mathrm{~h}^{-1}$ (mannose) and $0.64 \mathrm{~h}^{-1}$ (fructose). However, cells grown at $D=0.6 \mathrm{~h}^{-1}$ exhibited lower rates with mannose $\left(0.55 \mathrm{~h}^{-1}\right)$ and ribose $\left(0.53 \mathrm{~h}^{-1}\right)$, whereas for the other sugars the specific growth rates were between $0.60 \mathrm{~h}^{-1}$ (galactose) and $0.75 \mathrm{~h}^{-1}$ (fructose). However, in contrast to the uptake and growth rates with excess glucose, the specific growth rates which chemostatgrown cells achieved in batch culture with other sugars cannot be compared with the specific uptake rates of the corresponding sugars. The specific uptake rates reflect the expression of transport in the absence of the particular inducer, whereas in batch culture cells should have enough time to express the enzymes required for the utilization of the sugars. 


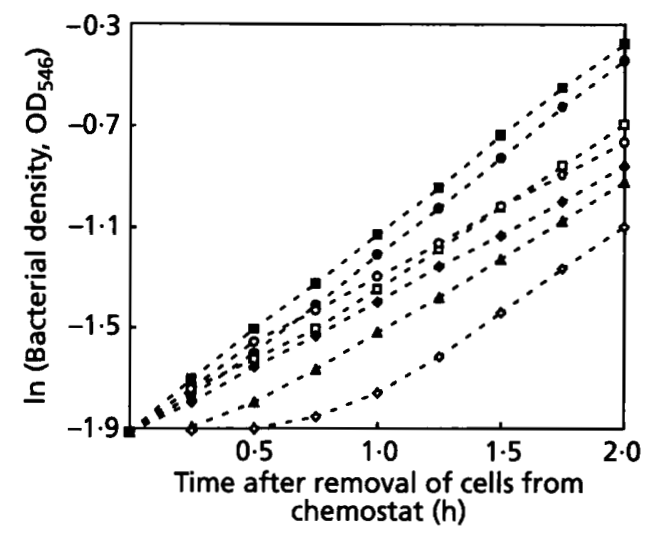

Fig. 4. Growth of $E$. coli cultivated in glucose-limited continuous culture at a dilution rate of $0.6 \mathrm{~h}^{-1}$ and transferred into batch culture with different carbon sources: glucose ( $\square$ ), fructose (O), mannose (O), maltose $(\square)$, ribose $(\diamond)$, galactose $(\Delta)$ and arabinose $(\diamond)$. Bacterial density was measured as $O D_{546}$ in a $1 \mathrm{~cm}$ cuvette.

An interesting observation is that cells grown at dilution rates of $0 \cdot 2 \mathrm{~h}^{-1}$ and $0 \cdot 3 \mathrm{~h}^{-1}$ exhibited higher specific uptake rates for maltose, ribose, mannose and galactose than the specific consumption rate of glucose seen previously in the chemostat (Fig. 3). Therefore, it is not surprising that $E$. coli grown in glucose-limited chemostat culture was able to immediately utilize these sugars. The only exception to this was the lag observed for growth with galactose (Fig. 4).

Unfortunately, there is little published information about the expression of transport systems in the absence of the corresponding inducer. Studies of regulation have focused mostly on the genetic mechanisms of induction or repression but rarely on the activity and actual substrate transport capacities for compounds other than the growth-supporting substrate. Considering the effects of catabolite repression, the high rates of uptake of sugars other than glucose is surprising, and therefore some of the conflicting points arising between our observations and the presently known behaviour of the different sugar transport systems will now be discussed.

\section{Fructose}

The initial specific uptake rate of fructose was very low (Fig. 2). This behaviour is consistent with the observation that the activity of PTS ${ }^{\text {Fru }}$ in E. coli was reported to be constitutive during growth with glucose but expressed at a level of only $10 \%$ of that found during chemostat growth with fructose (Clark \& Holms, 1976). However, PTS assays were made with toluene-permeabilized cells, and therefore the measured PTS activity does not necessarily correlate with transport. It was reported that PTS $^{\text {Man }}$ also transports fructose (Kornberg, 1990) but the results obtained in this study indicated that fructose uptake via PTS ${ }^{\text {Man }}$ is of only minor importance because the initial fructose uptake rate was very low in spite of the fact that mannose transport was expressed at a high level
(Fig. 3). This can be explained by the $K_{\mathrm{m}}\left(1800 \mathrm{mg} \mathrm{l}^{-1}\right)$ of Enzyme $\mathrm{II}^{\mathrm{Man}}$ for fructose (Postma \& Lengeler, 1985). Hence in an assay using an initial fructose concentration of $5 \mathrm{mg} \mathrm{l}^{-1}$ no detectable fructose transport can be expected via PTS ${ }^{\text {Man }}$.

\section{Mannose}

The expression of PTS ${ }^{\text {Man }}$ in E. coli requires increased levels of cAMP but not the presence of mannose as the inducer (Fraser \& Yamazaki, 1980). Therefore, a significant capacity for transport of mannose during chemostat growth of $E$. coli can be expected when the intracellular cAMP concentration is significantly higher in glucoselimited chemostat culture than during batch growth with glucose. There is evidence in the literature that under carbon-limited conditions levels of cAMP are increased (Magasanik \& Neidhardt, 1987; Makman \& Sutherland, $1965)$ and that catabolite repression seems to be absent (Ullmann, 1985). In E. coli B the inhibition of adenylate cyclase by extracellular glucose occurred over a narrow dose-response range, progressing from no inhibition at $10^{-5} \mathrm{M}\left(1.8 \mathrm{mg} \mathrm{l}^{-1}\right)$ to virtually complete inhibition at $10^{-4} \mathrm{M}$ (Peterkofsky \& Gazdar, 1974). For comparison, in chemostat culture steady-state glucose concentration rose to $1.8 \mathrm{mg} \mathrm{l}^{-1}$ only near wash-out rate (Senn et al., 1994). From the few publications on intracellular cAMP concentrations during chemostat growth, one reported that at a dilution rate of $0.2 \mathrm{~h}^{-1}$ in glucose-limited chemostat culture cAMP concentration was increased to 2.44 pmol $\left(10^{8} \text { cells }\right)^{-1}$ in comparison with batch growth on $0.1 \mathrm{~g}$ glucose $1^{-1}$ (Villarejo et al., 1978), where the cAMP concentration was only $0.54 \mathrm{pmol}\left(10^{8} \text { cells }\right)^{-1}$. Furthermore, it was shown that in ammonia-limited, glucose-containing chemostat cultures the intracellular cAMP concentration was about $0.3 \mu \mathrm{M}$, whereas under glucose-limitation this concentration increased to approximately $5 \mu \mathrm{M}$ (Wright $e$ t al., 1979). These examples indicate that in glucose-limited chemostat culture cAMP concentrations are probably one order of magnitude higher than in batch culture and hence the effects of catabolite repression are reduced or absent in glucoselimited continuous culture. Therefore, it is indeed possible that during glucose-limited chemostat growth the level of intracellular cAMP is high enough for expression of cAMP-dependent genes.

\section{Maltose}

Both inducer exclusion (Postma et al., 1992) and catabolite repression (Hengge \& Boos, 1983) affect maltose transport in the presence of glucose. Nevertheless, it was demonstrated that the enzymes of maltose utilization can be induced with exogenous glucose in the absence of maltose. Thereby, maltose and maltotriose, which serve as inducers for the maltose system, are formed intracellularly from glucose and glucose 1-phosphate (Decker et al., 1993). This leads to a constitutive nature of the maltose system (10-20\% of maximum induction) on the condition that glucose does not exert catabolite repression, because cAMP is also required for expression of 
maltose utilization (Lévy et al., 1990). From all sugars tested, the difference between the utilization patterns observed for batch- and chemostat-grown cells was most pronounced for maltose. During batch growth with glucose/maltose mixtures $E$. coli exhibited a considerable diauxic lag (Monod, 1942) whereas cells grown in glucoselimited chemostat culture immediately grew when presented with maltose.

\section{Ribose}

E. coli strains with either a constitutive or an inducible ribose utilization system are known (Abou-Sabé et al., 1982). For example, the ribose operon-encoding the binding-protein-dependent high-affinity transport system, ribokinase and the regulatory gene $r b s C$ - was constitutively expressed in $E$. coli $\mathrm{B} / \mathrm{r}$ but inducible in $E$. coli K12 (Abou-Sabé et al., 1982; Galloway \& Furlong, 1977). In this study ribose was transported immediately and provided growth without lag, indicating that in $E$. coli ML30 the ribose operon was constitutively expressed.

\section{Galactose}

Both the galactose binding-protein-dependent transport system (Mgl) and the proton symporter (GalP) are expressed constitutively in E. coli (Vorisek \& Kepes, 1972; Rotman et al., 1968) but both systems can be further induced to higher levels. Therefore, it is not surprising that galactose transport started immediately. Nevertheless, the reduction of the uptake rate after some $2 \mathrm{~min}$, and the considerable lag that occurred until growth started, indicated that one or more of the enzymes involved in the pathway of galactose to glucose 6-phosphate were not expressed sufficiently during chemostat growth of E. coli with glucose. Catabolism of galactose involves its phosphorylation to galactose 1-phosphate by galactokinase at the expense of ATP. Galactose-1-phosphate-uridyltransferase transfers galactose 1-phosphate to UDP-glucose with the release of glucose 1-phosphate. To complete the cycle, UDP-galactose is epimerized to UDP-glucose by UDP-galactose-4-epimerase (Adhya, 1987). The gal operon is not subjected to extensive catabolite repression (Ullmann \& Danchin, 1983). Nevertheless, in the absence of galactose the galETK operon encoding galactokinase, transferase and epimerase remained repressed (Lin, 1987) and both transferase and epimerase were present only at low levels (Adhya \& Echols, 1966). This explains why E. coli grown with glucose was able to transport galactose, but was unable to immediately use it to a significant extent as a growth substrate.

\section{Arabinose}

The two specific arabinose transport systems are both regulated by the $\mathrm{AraC}$ protein which represses their transcription in the absence of arabinose. Induction requires both arabinose and cAMP (Lin, 1987). Consequently no significant induction takes place in the absence of arabinose in the growth medium. It was reported that the binding-protein transport system of galactose was also able to transport arabinose (Furlong, 1987). However, the results obtained in this study show that cells of $E$. coli were not able to transport arabinose although galactose transport was obviously expressed (Fig. 3). This indicates that unspecific arabinose transport is probably negligible.

With the exception of the uptake of fructose, the biochemical findings reported above give a reasonable explanation why E. coli grown in glucose-limited chemostat culture was able to immediately take up mannose, maltose, ribose and galactose but not arabinose. However, the differing dependency of specific uptake rates on the dilution rate of pre-growth (Fig. 3) cannot yet be fully explained for the individual sugars. Nevertheless, the patterns found for maltose, ribose and galactose (Fig. 3) are in line with the generally found derepression of various catabolic enzymes with decreasing dilution rates (Matin, 1979). This derepression may be due to the reduced steady-state glucose concentrations at low dilution rates which possibly reduced the catabolite repression effect and increased induction by the global regulatory effect of cAMP. It is impossible to decide from our experiments whether or not this explanation is correct. An answer may be obtained from similar experiments with cells grown in chemostat culture with a sugar not causing catabolite repression.

\section{CONCLUSIONS}

Today, more than three decades after the discovery of bacterial permeases, it is still difficult to predict the utilization pattern of sugars by E. coli despite the fact that much is known about the genetics and biochemistry of sugar transport and the subsequent metabolism. One can conclude from our work that the extent of catabolite repression is lessened or even absent at low glucose concentrations. As a consequence, cells growing under such conditions should be able to utilize many other carbon substrates in combination with glucose, and also immediately replace one growth substrate with another. This is particularly relevant for understanding microbial growth under environmental conditions where concentrations of individual carbon sources are usually in the $\mu \mathrm{g}^{-1}$ range and the total available carbon rarely exceeds a few $\mathrm{mg} \mathrm{l}^{-1}$ (Münster \& Chróst, 1990).

\section{ACKNOWLEDGEMENTS}

The authors are indebted to Albert Tien for linguistic help. This study was supported by a grant of the Swiss National Science Foundation (NF 31-30004.90/2).

\section{REFERENCES}

Abou-Sabé, M., Pilla, J., Hazuda, D. \& Ninfa, A. (1982). Evolution of the D-ribose operon of Escherichia coli B/r. $J$ Bacteriol 150, 762-769.

Adhya, S. (1987). The galactose operon. In Eschericbia coli and Salmonella typhimurium, Cellular and Molecular Biology, pp. 1503-1512. Edited by F. C. Neidhardt, J. L. Ingraham, K. Brooks-Low, B. Magasanik, M. Schaechter \& H. E. Umbarger. Washington, DC: American Society for Microbiology.

Adhya, S. \& Echols, H. (1966). Glucose effect and the galactose 
enzymes of Escherichia coli: correlation between glucose inhibition of induction and inducer transport. J Bacteriol 92, 601-608.

Clark, B. \& Holms, W. H. (1976). Control of the sequential utilization of glucose and fructose by Eschericbia coli. J Gen Microbiol 95, 191-201.

Decker, K., Peist, R., Reidl, J., Kossmann, M., Brand, B. \& Boos, W. (1993). Maltose and maltotriose can be formed endogenously in Escherichia coli from glucose and glucose 1-phosphate independently of enzymes of the maltose system. $J$ Bacteriol 175, 5655-5665.

Egli, T., van Dijken, J. P., Veenhuis, M., Harder, W. \& Fiechter, A. (1980). Methanol metabolism in yeasts : regulation of the synthesis of catabolic enzymes. Arch Microbiol 124, 115-121.

Egli, T., Lendenmann, U. \& Snozzi, M. (1993). Kinetics of microbial growth with mixtures of carbon sources. Antonie Leeunenboek 63, 289-298.

El-Mansi, E. M. T. \& Holms, W. H. (1989). Control of carbon flux to acetate excretion during growth of Escherichia coli in batch and chemostat culture. J Gen Microbiol 135, 2875-2883.

Fraser, A. D. E. \& Yamazaki, H. (1980). Mannose utilization in Eschericbia coli requires cyclic AMP but not a exogenous inducer. Can J Microbiol 26, 1508-1511.

Furlong, C. E. (1987). Osmotic-shock-sensitive transport systems. In Escherichia coli and Salmonella typhimurium, Cellular and Molecular Biology, pp. 768-796. Edited by F. C. Neidhardt, J. L. Ingraham, K. Brooks-Low, B. Magasanik, M. Schaechter \& H. E. Umbarger. Washington, DC: American Society for Microbiology.

Galloway, D. R. \& Furlong, C. E. (1977). The role of ribose-binding protein in transport and chemotaxis in Escherichia coli K12. Arch Biochem Biophys 184, 496-504.

Harder, W. \& Dijkhuizen, L. (1976). Mixed substrate utilization in microorganisms. In Continuous Culture 6: Applications and New Fields, pp. 297-314. Edited by A. C. R. Dean, D. D. Ellwood, C. G. T. Evans \& T. Melling. Chichester \& Oxford: Ellis Horwood.

Harder, W. \& Dijkhuizen, L. (1982). Strategies of mixed substrate utilization in microorganisms. Phil Trans $\mathrm{R}$ Soc Lond B 297, 459-480.

Harvey, R. J. (1970). Metabolic regulation in glucose-limited chemostat cultures of Escherichia coli. J Bacteriol 104, 698-706.

Henderson, P. J. F. (1990). Proton-linked sugar transport systems in bacteria. J Bioenerg Biomembr 22, 525-569.

Henderson, P. J. F., Giddens, R. A. \& Jones-Mortimer, M. C. (1977). Transport of galactose, glucose and their molecular analogues by Escherichia coli K12. Biochem J 162, 309-320.

Hengge, R. \& Boos, W. (1983). Maltose and lactose transport in Escherichia coli examples of two different types of concentrative transport systems. Biochim Biophys Acta 737, 443-478.

Herbert, D. \& Kornberg, H. L. (1976). Glucose transport as ratelimiting step in the growth of Escherichia coli on glucose. Biochem J 156, 477-480.

Holms, W. H. (1986). The central metabolic pathways of Escherichia coli: relationship between flux and control at a branch point, efficiency of conversion to biomass, and excretion of acetate. Curr Top Cell Reg 28, 69-105.

Kornberg, H. L. (1990). Fructose transport by Escherichia coli. Phil Trans $\mathrm{R}$ Soc Lond B 326, 505-513.

Kornberg, H., Watts, P. D. \& Brown, K. (1980). Mechanisms of 'inducer exclusion' by glucose. FEBS Lett Suppl 117, K28-K36.

Leegwater, M. P. M. (1983). Microbial reactivity: its relevance to growth in natural and artificial environments. $\mathrm{PhD}$ thesis, University of Amsterdam, The Netherlands.
Lendenmann, U. (1994). Growth kinetics of Escherichia coli with mixtures of sugars. PhD thesis (no. 10658) Swiss Federal Institute of Technology, Zürich, Switzerland.

Lin, E. C. C. (1987). Dissimilatory pathways for sugars, polyols, and carboxylates. In Eschericbia coli and Salmonella typhimurium, Cellular and Molecular Biology, pp. 244-284. Edited by F. C. Neidhardt, J. L. Ingraham, K. Brooks-Low, B. Magasanik, M. Schaechter \& H. E. Umbarger. Washington, DC: American Society for Microbiology.

Lopilato, J. E., Garwin, J. L., Emr, S. D., Silhavy, T. J. \& Beckwith, J. R. (1984). D-Ribose metabolism in Escherichia coli K12: genetics, regulation and transport. J Bacteriol 158, 665-673.

Lévy, S., Zeng, G. \& Danchin, A. (1990). Cyclic AMP synthesis in Escberichia coli strains bearing known deletions in the pts phosphotransferase operon. Gene 86, 27-33.

Magasanik, B. \& Neidhardt, F. C. (1987). Regulation of carbon and nitrogen utilization. In Escherichia coli and Salmonella typhimurium, Cellular and Molecular Biology, pp. 1318-1325. Edited by F. C. Neidhardt, J. L. Ingraham, K. Brooks-Low, B. Magasanik, M. Schaechter \& H. E. Umbarger. Washington, DC: American Society for Microbiology.

Makman, R. S. \& Sutherland, E. W. (1965). Adenosine $3^{\prime}, 5^{\prime}$ phosphate in Escherichia coli. J Biol Chem 240, 1309-1314.

Mateles, R. I., Chian, S. K. \& Silver, R. (1967). Continuous culture on mixed substrates. In Microbial Pbysiology and Continuous Culture (Proceedings of the 3rd International Symposium), pp. 232-239. Edited by E. O. Powell, C. G. T. Evans, R. E. Strange \& D. W. Tempest. Porton Down, Salisbury, UK: Her Majesty's Stationery Office.

Matin, A. (1979). Microbial regulatory mechanisms at low nutrient concentrations as studied in chemostat. In Strategies of Microbial Life in Extreme Environments, pp. 323-339. Edited by M. Shilo. Weinheim, New York: Verlag Chemie.

Meadow, N. D., Fox, D. K. \& Roseman, S. (1990). The bacterial phosphoenolpyruvate:glycose phosphotransferase system. Annu Rev Biocbem 59, 497-542.

Monod, J. (1942). Recherches sur la Croissance des Cultures Bactériennes. Paris: Hermann.

Münster, U. \& Chróst, R. J. (1990). Origin, composition, and microbial utilization of dissolved organic matter. In Aquatic Microbial Ecology Biochemical and Molecular Approaches, pp. 8-46. Edited by J. Overbeck \& R. J. Chróst. New York: Springer.

Neijssel, O. M., Hueting, S. \& Tempest, D. W. (1977). Glucose transport capacity is not the rate-limiting step in the growth of some wild-type strains of Escherichia coli and Klebsiella aerogenes in chemostat culture. FEMS Microbiol Lett 2, 1-3.

Peterkofsky, A. \& Gazdar, C. (1974). Glucose inhibition of adenylate cyclase in intact cells of Escherichia coli B. Proc Natl Acad Sci US A 71, 2324-2328.

Postma, P. W. \& Lengeler, J. W. (1985). Phosphoenolpyruvate: carbohydrate phosphotransferase system of bacteria. Microbiol Rev 49, 232-269.

Postma, P. W. \& Lengeler, J. W. (1993). Phosphoenolpyruvate: carbohydrate phosphotransferase systems of bacteria. Microbiol Rev 57, 543-594.

Postma, P. W., Ruijter, G. J. G., van der Vlag, J. \& van Dam, K. (1992). Control of carbohydrate metabolism in enteric bacteria: qualitative and quantitative aspects. In Molecular Mechanisms of Transport, pp. 97-105. Edited by E. Quagliariello \& F. Palmieri. Amsterdam: Elsevier.

Rotman, B., Ganesan, A. K. \& Guzman, R. (1968). Transport systems for galactose and galactosides in Escherichia coli. J Mol Biol $36,247-260$. 
Saier, M. H. (1991). A multiplicity of potential carbon catabolite repression mechanisms in prokaryotic and eukaryotic microorganisms. New Biol 3, 1137-1147.

Senn, H., Lendenmann, U., Snozzi, M., Hamer, G. \& Egli, T. (1994). The growth of Escherichia coli in glucose-limited chemostat cultures: a re-examination of the kinetics. Biochim Biophys Acta 1201, 424-436.

Ullmann, A. (1985). Catabolite repression 1985. Biochimie 67, 29-34.

Ullmann, A. \& Danchin, A. (1983). Role of cyclic AMP in bacteria. Adv Cyclic AMP Res 15, 1-53.

Villarejo, M., Stanovich, S., Young, K. \& Edlin, G. (1978).

Differences in membrane proteins, cyclic AMP levels, and glucose transport between batch and chemostat cultures of Escherichia coli. Curr Microbiol 1, 345-348.

Vorisek, J. \& Kepes, A. (1972). Galactose transport in Escherichia coli and the galactose-binding protein. Eur J Biochem 28, 364-372.

Wright, L. F., Milne, D. P. \& Knowles, C. J. (1979). The regulatory effects of growth rate and cyclic AMP levels on carbon catabolism and repression in Escherichia coli K12. Biochim Biophys Acta 538, 73-80.

Received 5 July 1994; revised 26 September 1994; accepted 29 September 1994. 